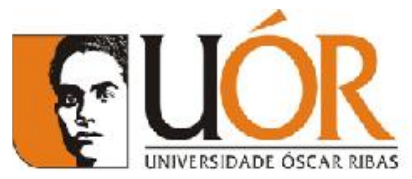

\title{
LA IZQUIERDA ESTUVO EQUIVOCADA Y ES TIEMPO DE LA INSUMISIÓN
}

The left was wrong and it is time of the insumision / A esquerda esteve equivocada e é tempo da insubordinação

Robinson Salazar ${ }^{1}$

\section{RESUMO}

A presente reflexão tem a intenção de calçar as premissas para um debate que nos obrigue a elaborar conjenturas, propor novas ideias, debater sobre o percurso dos movimentos populares depois das derrotas sofridas com a implementação dos governos "progressistas", cuja característica maior foi monopolizar o poder, desde uma casta burocrática que impediu a incubação do sujeito político-popular necessário e insubistituível, ao alcance uma transformação social profunda, irreversível e com perfil emancipatário. Ficou demostrado que não é possível forjar um sujeito, nem mesmo inventá-lo com retórica ou relatos estimulando o popular, mas negando ao povo o seu papel protagonista. A insubordinação com rostro, conciência e praxis só é possível em sujeito insubordinado, recriado na luta, na confrontação, na direcção das tarefas de transformação e assumindo a liderança que sempre tem reclamado, nas tentativas revolucionárias de América Latina.

Palavras-chaves: Sujeito, insubordinação, governos progressistas, emancipação.

Recebido: Novembro 2017

Aceitado: Dezembro 2017

\section{RESUMEN}

La reflexión que presentamos lleva la intención de sentar las premisas para un debate que nos obligue a elaborar conjeturas, proponer nuevas ideas, debatir sobre el derrotero de los movimientos populares después de las derrotas sufridas con el experimento de los gobiernos "progresistas", cuya característica mayor fue monopolizar el poder desde una casta burocrática que impidió la incubación del sujeto político-popular necesario e irremplazable para lograr una transformación social profunda, irreversible con perfil emancipatorio. Quedó demostrado que desde el Estado no es posible forjar un sujeto, tampoco inventarlo con retórica o relatos ensalzando lo popular pero negándole al pueblo su papel protagonista. La insumisión con rostro, conciencia y praxis sólo es posible en el sujeto insumiso, recreado en la lucha, la confrontación, en la dirección de las tareas de transformación y asumiendo el liderazgo que siempre ha reclamado en los intentos revolucionarios de América Latina.

${ }^{1}$ Doctor en Ciencias Políticas y Sociales. Es Investigador en la Universidad Autónoma de Sinaloa (UAS). Sinaloa, México. Correo Electrónico: salazar.robinson@gmail.com 
Palabras claves: Sujeto, insumisión, gobiernos progresistas, emancipación.

\begin{abstract}
Reflection that we present is intended to lay the premises for a debate that forceus to make guesses, propose new ideas, discuss the course of people's movements after the defeats suffered with the experiment of the "progressive" governments, whose main characteristic was monopolizing since a bureaucratic caste that prevented the incubation of the politico-popular subject necessary and irreplaceable to achieve a social transformationdeep, irreversible with emancipator profile. It was demonstrated that from the State it is not possible to forge a subject, nor invent it with rhetoric or stories extolling the popular, but denying the people their leading role. The insubordination with face, conscience and praxis is only possible in the rebellious subject, re-created in the struggle, the confrontation, in the direction of the transformation tasks and assuming the leadership that has always claimed in the revolutionary attempts of Latin America.
\end{abstract}

Key words: Subject, insubordination, progressiveGovernments, emancipation

\title{
Palabras preliminares
}

La crisis insoslayable de Venezuela a partir del segundo semestre de 2017 abrió el debate con mayor ahínco dentro de los círculos académicos, intelectuales $y$ en las redes sociales. Los factores de mayor preponderancia en las mesas de confrontación ideológica son los que tienen que ver con el fin de ciclo de los gobiernos "progresistas" que tuvieron años de actuación con márgenes de maniobra amplios dado que los precios de las materias primas escalaron a niveles pocas veces visto y el contar con un modelo extractivista y exportador de productos primarios favoreció las arcas de los erarios de los países latinoamericanos.

Otro factor que arrimaron a la mesa de diálogos ríspidos fue el carácter de los gobiernos, algunos escritores fincan sus recursos argumentativos en defender un proyecto socialista de Siglo XXI y otros el carácter popular con vetas emancipadoras, sin embargo, las dos caras de este problema no están de acuerdo con la realidad social y política de las naciones que tuvieron y otros aún mantienen los procesos políticos con perfil "progresista".

La disputa de espacios y poder entre la derecha latinoamericana y los movimientos progresistas ha llegado a una etapa de confrontación áspera y con 
medición de fuerzas para controlar a la región. Los avances y formas de comportamiento que tuvo el progresismo pecó de errores que en el pasado se habían cometido, excesivo liderazgo compulsivo, elaboración de un discurso encapsulador y vertical, dirección sin incorporación de ingredientes populares, retórica constructora de realidad desde la alocución, abandono de los empoderamientos en los espacios ocupados por el trabajo y la cotidianidad, y vacío en la estructura orgánica para controlar el poder.

Mientras los gobiernos "progresistas" acordaban alianzas prosperas y utópicas, la derecha orgánica con el soporte de los medios de comunicación, afinó la estratega de apropiación, limó la base económica, desdibujó la estructura financiera que brindaba soporte a los gobiernos progresistas, atomizó a la sociedad y la orientó hacia un cuestionamiento de lo popular a través de inducción a la alegría, el consumo, la libertad, libre cambio monetario, vinculación de la nación con el mundo, la globalización y las nuevas tecnologías.

Dos concepciones de la sociedad en disputa y un resultado que reclama un reposicionamiento de las fuerzas populares en América Latina.

\section{Introducción}

Los acontecimientos ocurridos en los últimos dos años trajeron una ola de especulaciones, conjeturas y postulados teóricos por comprender qué está sucediendo con las fuerzas progresistas en América Latina y cuál es el rumbo que tomaron los sucesos en los primeros meses del año 2017. Afirman ciertos sectores académicos y políticos el fin de una etapa de gobiernos nacional-popular; otros esgrimen argumentos no convalidados con la realidad, de que llegó la hora del repliegue y resistencia popular; no quedan fuera de foco y del debate aquellos que ven con pesimismo la derrota de la etapa "popular" y están convencidos que la fuerza de la derecha llego con dinamismo e inexorablemente va a perdurar por varios años.

El marco de las actuaciones gubernamentales está atrapado en discusiones sobre las gestiones impopulares y esos signos son interpretados como el fin, decadencia o fortalecimiento del neoliberalismo, sin embargo la crisis del modelo 
no se detiene si lo observamos por los magroresultados en la inclusión, la tendencia incremental de la pobreza y el cierre de los espacios de expresión democrática. Lógicamente esta es una visión desde la ventana de la izquierda. Si nos asomamos por la vidriera de la derecha, las consecuencias de la aplicación de las políticas neoliberales trajo y sigue reportando grandes beneficios a los empresarios, multinacionales, inversores extranjeros, banca multinacional, empresas mineras, la industria de la creatividad y exportadores de materia prima. Todo depende del cristal que usemos para observar la realidad.

Desde la izquierda avizoramos una crisis profunda que puede detonar en un estallido social, no obstante los espacios y el sujeto provocador de la ruptura está ausente en los análisis; desde la otra orilla, el clima para inversores está dado, las modificaciones que las nuevas tecnologías están provocando en las subjetividades colectivas de los jóvenes y universidades-tecnológicos son dispositivos favorables para anular una revuelta social y favorecer la dispersión, la competitividad, la insularidad e individualidad fragmentaria en sociedades como las que predominan en América Latina.

La nube cargada de expectativas por ser parte de un mundo inteligente, tecnológico, virtual, creativo y de consumo es una estela densa que está incrustada en las formas de pensar de un segmento de la sociedad que va entre los 14- 34 años los mismos que están identificados con la derecha, deciden los procesos electorales, no están interesados en los debates ideológicos, no sienten estar excluidos, les atrae el uso de los dispositivos electrónicos y dibujan en su subconsciente un mapa de la realidad alejada de la geometría política de izquierda-derecha, y con mayor énfasis en preceptos neoliberales que consisten en aprender a hacer negocios, incrementar la eficiencia operativa, desarrollar nuevos mercados, innovar portafolio de productos y servicios, y agregar nuevo valor financiero. Todo ello para ser parte del mundo empresarial y no del campo de los trabajadores.

En el choque de ideologías, la derecha avanzó con pasos firmes, ha desplazado al pensamiento crítico de las universidades, lo poco que quedó lo arrinconó en condición calamitosa, sin recursos ni apoyos logísticos para 
investigar y divulgar el conocimiento; el emprendurismo, la creatividad, la innovación, el uso de nuevas tecnologías, el realce del talento ligado a creación de negocios y empresas sedujo, cultivó y organizó la cultura de los jóvenes que hoy día no están interesados en explicaciones ni debates ideológicos, en cambio la flexibilidad, la desterritorialización laboral, la movilidad estudiantil, trabajo, reuniones, aprendizajes y educación en online fue la pauta del mundo virtual que nos presiona y nos homogenizará en el 2020.

Se presenta entonces este artículo de modo particular (estilo ensayo), con la finalidad de llevar a cabo una reflexión para el debate sobre las premisas que han usado los movimientos populares y las derrotas sufridas con el experimento de los gobiernos "progresistas".

\section{Lo nacional popular o megalomanía política emancipatoria}

El arribo de los gobiernos autodenominados nacionales, populares y Socialismo Siglo XXI no devino de un trabajo previo en el ámbito organizacional, tampoco de redes asociativas con plan de competencia política. Fue un alud de hartazgo y descontento por los efectos de las privatizaciones, la necesidad de hallar un horizonte de certidumbre, probar con personajes nuevos y no viciados de la política tradicional.

El tiempo transcurrido entre el Caracazo de febrero de 1989 y el triunfo electoral de diciembre de 1998 no está marcado por un trabajo intenso de base ni de núcleos poblacionales en redes. Fue un desgaste en Venezuela que había llegado a su punto de inflexión por la corrupción, la desigualdad social, 7 millones de personas no eran parte de la población identificada ni con derechos, un desorden administrativo en PDVSA, militares coludidos con el régimen y una clase media venida a menos que veía agotar sus recursos y espacios de movilidad social. Ahí encalló el barco del eje AD-COPEl y dio paso al gobierno de Hugo Chávez Frías, con un inicio sin horizonte claro en la política, algunas veces dio muestras de simpatía por la social democracia, otro día cercano a la teología de la liberación y fue su cercanía con Fidel Castro lo que hizo cambiar su ideología, afinar sus baterías y trabajar en el proyecto del Socialismo Siglo XXI. 
De manera similar transitó Argentina, con el estallido de la crisis 2000-2001, confiscación de depósitos bancarios y cierre masivo de empresas y fábricas, una postura de gobierno transversal que propuso Néstor Kirchner brindó la oportunidad de un triunfo electoral con el $22.3 \%$ en el año 2003. Su recorrido fue dentro del marco neoliberal y en 2008 Cristina Fernández arriba a la presidencia sin romper los marcos globales y sí con alguna tirantez con Estados Unidos, sin confrontarlo frontalmente, mediado el desencuentro por la cercanía con el gobierno de Venezuela que para esos años ya había radicalizado su discurso confrontado contra George Bush para entonces presidente de EE.UU; además, tensiones fuertes sostuvo frente al grupo de deudores denominados "Buitres" que exigían altos intereses en el cobro del préstamo otorgado en los momentos en que Argentina transitaba por condición apremiante.

Bolivia en la era de Evo Morales tiene un punto de partida interesante, la alianza entre Confederación Sindical Única de Trabajadores Campesinos de Bolivia (CSUTCB) y el Movimiento al Socialismo-MAS- unieron capital orgánico, espacios estratégicos, discursos nacionalistas, candidatura única y sólido respeto en las decisiones de la dirigencia, fue así que en 1997 eligieron a Evo Morales como diputado, quien desempeño un papel activo en denuncias, defensa del indígena, lucha sindical y presencia de los nativos en distintos espacios de la vida pública, esta intensa actividad personal y colectiva con soporte de la alianza capitalizó el desgaste de la dirigencia ancestral de la oligarquía boliviana y en 2005 obtuvo la presidencia en las elecciones de diciembre de ese año, tomando posesión en enero 2006.

Para el caso de Rafael Correa, entre octubre y noviembre de 2006, en dos vueltas, fue decidido el proceso de elección presidencial en Ecuador. Electo Correa, con antecedentes en el gobierno de Alfredo Palacios como ministro de economía, apoyado por la agrupación Alianza PAIS (Patria Altiva y Soberana) y Partido Socialista - Frente Amplio. En el 2005 bajo el paraguas de la Alianza PAÍS se reveló como un político promotor de una Constituyente y fue así como en la segunda vuelta con alianza orgánica entre Movimiento Popular Democrático, Izquierda Democrática, Pachakutik, Partido Roldosista Ecuatoriano derrotaron a 
Álvaro Noboa. Ya en función de gobierno, fue hasta la segunda oportunidad electoral cuando le apostó a la reelección en 2009 y Rafael Correa radicaliza su postura en la medida que el ambiente latinoamericano lo permeaba con procesos políticos populares y es notoria la aproximación hacia el grupo de gobiernos de perfil nacional-popular, para esos años el discurso de Socialismo Siglo XXI, fue de transformación Nacional-Popular, revolución pluriétnica, Teología de la Liberación con Fernando Lugo en Paraguay quien en 2008 había ganado las elecciones presidenciales, dotaban a Suramérica de un nutrido grupo de gobernantes que hacían alianzas, algunas discursivas, otras comerciales e integracionistas, bajo la égida inteligente, pausada y negociadora de Luizlnácio Lula da Silva, presidente desde 2003-2010), las provocaciones político-verbales de Hugo Chávez, las confrontaciones ante los medios de Rafael Correa, la puntual participación de Evo Morales, y con menos impacto en el continente Fernando Lugo y el matrimonio Kirchner.

Las conductas de los dirigentes mencionado fueron manifiestas en momentos de negociación o conflictos, una de ellas fue las constantes discordias entre el presidente Uribe de Colombia y Hugo Chávez de Venezuela, cuyas expresiones conflictivas estuvieron en los linderos de la guerra pero fueron atenuadas por la mesura de Lula. Otro caso que evidenció el liderazgo compulsivo de Chávez fue en la liberación y entrega de prisioneros que las FARC de Colombia tenía bajo su custodia y como gesto de negociación regresaba al gobierno colombiano. La mediación en un episodio tuvo a Néstor Kirchner entre los intercesores al igual que al presidente venezolano pero quisieron imponer algunas reglas del juego a la guerrilla colombiana, en episodios que tenían que ver con el formato de entrega de prisioneros.

El liderazgo compulsivo chocó con la naturaleza de las FARC, ejército guerrillero que desde su nacimiento guarda una autonomía que estuvo blindada por más de 50 años, sin aceptar influencias ni injerencias de la ex URSS, China, Albania, Cuba e incluso de la corriente guevarista que prevaleció en América Latina. Intentar incidir en el mundo político de las FARC es terreno minado, dado 
que es una organización con jerarquía, relevo de liderazgos locales, alternancia de dirigencia, ideología nacional revolucionaria y de firme convicción marulandista.

El choque del liderazgo compulsivo con las FARC marcó una distancia entre el gobierno de Venezuela y la guerrilla colombiana, aun cuando los alzados en armas fueron fuerza coadyuvante que contuvo a los paramilitares en la zona del Catatumbo y en Arauca y Arauquita para que no tuviesen un zaguán de infiltración hacia el territorio venezolano, por parte de Chávez no hubo esa reciprocidad, antes por el contrario, hubo un gesto que incomodó a la dirigencia de las FARC por la entrega inapropiada que el presidente venezolano hizo de Pérez Becerra, editor de la agencia con sede en Estocolmo Anncol, a la justicia colombiana, cuyo procedimiento inaudito, fuera de toda conducta revolucionaria y complaciente con Uribe, denostó el internacionalismo revolucionario y acomodó su respuesta a una salida simple, mezquina y sin ánimo de autocrítica. Todo esto sucedió en el año 2011 (Serrano, 2011).

Indudablemente que el papel de asesoría permanente de Cuba y acompañamiento de Fidel Castro hasta antes de su enfermedad, dio bríos al grupo que ideológicamente no era monolítico, pero brindaban hacia el exterior esa apariencia, de solidez en valores, principios y estrategias, fincando esos propósitos en los logros obtenidos de No al ALCA, creación del ALBA, UNASUR, CELAC, cuyos foros fueron ágiles y con marcada autonomía, sin embargo las materializaciones fueron pocas, quedando en la mesa de proyectos el banco regional, la integración de las economías, la complementariedad para el desarrollo y una integración logística-vial que diera vida a las economías regionales, integrara zonas y áreas alejadas del intercambio económico y armara un verdadero mercado regional, porque el Mercosur no es hasta ahora la mejor opción, dado que es Brasil y después Argentina los beneficiados, las demás naciones no son impactadas por el proceso integracionista.

Entonces la organización popular no fue el ingrediente básico, salvo Brasil el cual contaba con la tradición sindical del Partido de los Trabajadores, Movimientos Sin Tierra y otras ligas movimientistas que brindaron soporte a la candidatura de Lula. En los demás casos, los intentos de organicidad iniciaron 
después de asumir la presidencia, incluso, para el caso venezolano los partidos de izquierda pusieron a disposición de Hugo Chávez sus estructuras organizativas, pero al momento del El Partido Socialista Unido de Venezuela (también conocido por sus siglas; PSUV) los intereses, rupturas, tensiones y desbandadas fue la música entonada por los grupos integrantes hasta que aparecieron la constelación de partidos minúsculos y una burocracia paquidérmica dentro del PSUV que no funciona como esperaban y revela signos de agotamiento por las tribus que existen en su interior.

En cuanto a la eficacia de las relaciones económico-comerciales entre el grupo de países con gobierno nacional-popular, hay datos poco significativos, dado que los intercambios de Argentina con Brasil y Uruguay, vecinos cercanos y miembros del Mercosur fue conflictiva, tirante y con signos de descontento. Uruguay siempre tuvo quejas contra Argentina cuyo comercio llegó a ser imperceptible, y con Brasil tuvo reclamos por los bloqueos que el gigante puso al arroz. Argentina y Uruguay auxiliaron a Venezuela, el saldo es deuda impagable por parte del gobierno de Nicolás Maduro a Uruguay (Territorio Digital, 2016).

Venezuela sólo exporta petróleo en la región, alianzas con Petrobras quedaron en anuncios, con Bolivia hizo algunas operaciones discontinuas al igual que lo hizo con Argentina. En síntesis, la integración económica-comercial transitó más por la retórica que por los camino de la eficiencia, algo común en la ecuación algebraica de la izquierda en el poder desde 1979 con la Revolución nicaragüense y ahora los ejercicios de proyectos nacional-popular.

\section{Vicios, limitaciones y mucho por corregir}

El Liderazgo compulsivo con discurso inapelable borró las diferencias y particularidades de cada sector popular. La modulación de relato que unía con cemento vertical una pieza discursiva que definía a la nación, al pueblo, el destino y hasta la forma de hacer política de manera casi proverbial, sin dejar posibilidad abierta de una discusión de qué trataba, de dónde devenía esa definición, quién la propuso y cuál era su contenido ideológico . Fue un discurso impuesto, nada plural 
ni democrático, sólo había que repetirlo, servir de caja de resonancia e insertarlo en cada poro del extenso cuerpo de la sociedad.

Todo aquel que osara discutir, indagar, cuestionar o cuestionarse qué era la lucha de lo nacional popular o el Socialismo Siglo XXI pasaba a las filas del enemigo, la consigna fue, obedecer y marchar como soldados de una revolución, modelo que fracasó con el socialismo real y aun en el Siglo XXI trataron de imponer.

La sociedad latinoamericana no tiene dos sectores, es pluriétnica, diversa, plural, similar al arcoíris, existen jóvenes, pero dentro del rubro los hay indígenas, gays, trabajadores, estudiantes, intelectuales, profesionistas, ama de casa, padres de familia, en fin, no es una categoría social cerrada, antes por el contrario, ser joven es un sujeto multidimensional porque ser indígena a la vez asume rol de estudiante, padre de familia y luchador social, al igual pasa en otros sujetos que re-dimensionan su identidad adquirida.

Tratar de imponer un discurso de jóvenes y en el mismo costal incluir a todos es una necedad o actitud intolerante ante la realidad, es ceguera mental y comportamiento vertical ante los demás.

Un ejemplo lo pude observar en Venezuela, el discurso de Hugo Chávez con respecto a los indios wayúu o guajiros, siempre tuvo signado como gente del estado del Zulia, sin reconocerle sus particularidades y en los momentos en que los wayúu reclamaron demandas justas, fueron calificados como opositores y seguidores de los escuálidos como solía llamársele a los opositores. Los wayúu no fueron enganchados en las transformaciones de la revolución bolivariana por la sencilla razón de que no los reconocieron como sujeto indígena, los chavistas bolivarianos son todos con un sello uniforme, una voz guiada desde el poder y unas demandas impuestas por la dirigencia, lo demás sobraba en la arena política. Así fue dándose la construcción social de la realidad mediante pieza discursiva inventada por los dos bandos: los aliados y los enemigos. La centralidad discursiva y la hegemonía ideológica borró la pluralidad, los tintes y sellos de cada sector, construyó una unidad en el discurso pero la ahondó y fragmentó en la práctica. 
Dotaron de derechos a la población en el discurso no en lo espacial, el empoderamiento requiere y demanda un espacio particular que el sujeto emancipatorio hace suyo y lo convierte en espacio estratégico. Si lo empoderas en lo discursivo y fuera de su espacio, lo volatilizas, es masa acarreada no masa empoderada y poco dispuesta y resuelta a construir acciones colectivas en su favor.

Las masas acarreadas en la mayoría de veces obedecen consigna, "Comandante Mande", " la Dirección ordena", esas consignas monopolizan el ejercicio del poder, hace obediente al sujeto y ante todo, lo eclipsa, le rompe sus dispositivos de actuación colectiva, sus resortes creativos y la voluntad de actuar en función de sus necesidades y demandas. Si lo adocenas, lo doblegas a la obediencia del jefe o jefatura colectiva, crecen en él tentáculos aprisionadores de voluntad y decisión, relega su independencia, espera siempre órdenes, supedita sus derechos y demandas a la jefatura, renuncia a la lucha y poco a poco es convertido en un obcecado obediente de la nomenclatura burocrática.

No hubo entonces un discurso propio para el indígena, el obrero, el campesino, el profesionista, los jubilados, los jóvenes, estudiantes, mujeres, gays entre otros, todo se introdujo en una pieza discursiva, borrando diferencias y particularidades; no hizo notorio las demandas complementarias, la ligazón de un derecho indígena con los jóvenes estudiantes, sino que en un costal poroso y roto metió a todos bajo un lema Nacional-Popular vacuo, sin forma ni contenido de ahí que hoy armar una demanda les cuesta mucho para darle cuerpo y dotarla de contenido e insertarla en el contexto de lucha. Lo nacional es tan grande como insignificante, lo popular es todo y nada, nadie quiere asumirse como perdedor y explotado, sino como sujeto despojado de sus derechos, es una contradicción, son expropiados pero no explotados.

Empoderarlos no era proporcionarles un salario o plan de ayuda menesterosa, sino exigirles, guiarlos, inducirlos a crear, producir, colectivizar los saberes y experiencias, rotular su espacio con una praxis colectiva, un sello de ejercicio político, un quehacer productivo a fin de generar una apropiación del 
sitio, el lugar y el espacio, convirtiéndolo en una trinchera de trabajo, mundo de vida y defensa política.

Otro tema de anomalía orgánica fue el modelo reproductivo de la cadena burocrática difusora y resonante caja de discurso nacional-popular, el cual ahuyentó la participación, sometió al militante, congeló la crítica, aplazó los anhelos libertarios, selló las puertas del debate y sólo la reproducción del mensaje de arriba era escuchado y repicaba como canto de iglesia o sermón de retiro espiritual.

El descontento fue filtrándose hacia canales opositores, el hartazgo abrió caminos que lo conducían al adversario, el enemigo eufórico ofrecía alegría, trabajo y libertad, obviamente no le explicaba bajo qué condiciones ni los entramados de su paradigma, la burocracia "progresista" ebria de derroche creyó que controlaba almas con prebendas y migajas, acarrear es mejor que explicar, lógica fácil en políticos inútiles.

Institucionalmente, el gobierno nacional popular o revolucionario no legitimó sus estructuras, el gobierno fue y era la persona que podía cambiar el curso de la historia, los acontecimientos, las fechas, los eventos, el tiempo y hasta la verdad. El discurso fue pudriéndose, fétido olor despedía en los actos y movilizaciones pagadas, las voz muda de los distintos sectores populares solamente eran escuchadas para gritar consignas pero no sus demandas, hacerlo era colocarse en la acera de la enemistad.

Le quitaron valor al Estado, a las leyes, a los gobernantes locales y regionales, a los símbolos, todo era el rey, el líder, el omnipresente que cada día que pasaba, sus pies iban perdiendo fuerza y los seguidores sin brújula cantaban el son de la música ensordecedora de victoria para siempre.

La experiencia ganada en movilización y organización fue diluida en obediencia, los signos de corrupción fueron notables, no equiparables con las políticas de distribución, que con el pasar de los meses y la caída de los precios de los commodities (productos de la cesta básica) fue reduciendo los planes de apoyos a los carenciados, la inflación vino como lluvia con la impresión de billetes y el 
discurso no podía estirarse más de lo que cubrían las mentiras que poco a poco desocultaban lo hecho mal o de manera arbitraria.

La subordinación de los movimientos populares a directrices de partido o gobierno adocena e impide el desarrollo de formas políticas autónomas surgidas desde los de abajo; la dispersión es cierto que refuerza búsquedas genuinas de participación y nuevas formas de representación. Pero la excesiva partidización es también un factor que dispersa y abre los grifos de fuga y expulsa a sectores populares por el abuso del centralismo vertical.

En época de crisis la supervivencia asoma la cabeza, y fueron los sectores desocultados los primeros en transitar a la oposición, la carrera de quien acapara más gana fragmentó el cuerpo de lo popular, los hilos de conducción sufrieron de esclerosis múltiple, el éxodo fue en los 4 lados de cuadrilátero con destino indeterminado, la débil estructura orgánica implosionó por desesperación, desencanto o desacompañamiento.

Frei Betto nos regala una reflexión resumida pero esclarecedora sobre el tema abordado: "no han tratado de organizar y politizar al pueblo, un gobierno progresista no se mantiene por consignas, por promesas. Los pueblos pueden soportar la dificultad, como pasa en Cuba, si tiene formación ideológica para comprender esa dificultad y estar dispuestos al sacrificio...No hicieron un trabajo de base, en el sentido de organizar políticamente al pueblo, y ese pueblo está sujeto y por tanto vulnerable, a toda la propaganda de la prensa burguesa...muchos movimientos sociales ya no actuaron con decisión, con coraje, 'estamos esperando que el gobierno va a hacer esto, que el gobierno va a apoyarnos', y el gobierno no apoyó. El gobierno ha sido muy bueno en muchos aspectos, pero ha sido bastante padre de los pobres y madre de los ricos ...mucho asistencialismo, es factor preponderante. Han tratado de facilitar o que el pueblo se haga de bienes personales: computadora, nevera, teléfonos celulares, y no los bienes sociales: educación, salud, vivienda, saneamiento, transporte colectivo..." (Martínez, 2016).

La experiencia es costosa, dolorosa y lamentable, porque retrasar de nuevo las metas, replantear formas de organización, retomar ejercicios exitosos y 
depurar lo que nos ha provocado golpes y caídas es un tramo largo, necesario y con discusiones inteligentes. Los protagonismos mesiánicos deben ser guardados en el baúl de las experiencias nefastas, las actuaciones compulsivas son ingredientes sobrantes y vinagretas indigestas de todo proceso político emancipatorio. Los caminos transitados en el ayer no son senderos de victoria en el ahora, pero son parte del arsenal analítico de ayuda a comprender la realidad social circundante. Tenemos un enemigo poderoso, hábil, mutante, con muchos recursos y desplazamiento, sus alianzas estratégicas son numerosas, tecnológicamente nos atropella y sabe seducir con el lenguaje.

$\mathrm{Si}$ reconocemos que el enemigo tiene formas diversas de dominios y acervos político-militares para imponer su control, no juguemos a David y Goliat, ni lo confrontemos con retóricas triunfalistas que lo enmarcan en una crisis terminal y agonizante. No está en peligro elneoliberalismo, No está en riesgo el imperialismo, No está en crisis el narco capitalismo, No está en un escollo el capital monopólico financiero, la crisis la reflejamos quienes carecemos de una capacidad analítica de razonar y ver al gigante que nos atropella y quiere mantener el dominio eterno.

La diversidad es fortaleza, de ahí que los distintos movimientos populares, comunitarios tienen caída en la nueva organicidad, sin perder su autonomía, cúmulo de demandas, dinámica comportamental, formas de lucha y trayectoria de trabajo político. Su incorporación a un frente o alianza popular no borra sus particularidades, las ahonda y las articula con otras organizaciones, complementariedad en la lucha, escalonamiento de demandas, dinámicas de confrontación moduladas, enlaces de desplazamiento y movilizaciones, boicot espacial y creación de encadenamiento de espacios estratégicos y otros autónomos para confrontar en momentos de la represión profunda.

Rotación de liderazgos, descubrir nuevos enclaves de líderes locales, comunitarios, regionales con relevo, despliegue y soporte de cuadros intelectuales que lo alimenten con reflexiones novedosas y apegadas a la realidad cambiante. Un líder eterno es signo de una sociedad descabezada, muda, obediente y $\sin$ 
acervo de insumisión. Muchas cabezas decididas a pensar y resolver, es el holograma de una sociedad despierta que reclama, exige y lucha por su libertad.

\section{Las decisiones obstinadas e incorregibles de la democracia centralista}

Un elemento crucial en todo proceso político con perfil netamente liberador o emancipador, es la vigilancia, en tanto la concibamos como el instrumento orgánico celoso, crítico, acompañante y dotado de cobertura social y política que resida en el partido o frente aglutinador de fuerzas revolucionarias que cuida y vigila que los postulados y compromisos adquiridos por la insurgencia sean cumplidos una vez arribe al poder.

Ahora bien, garantizar la factibilidad de esa condición es necesario que la fuerza política (partido o convergencia de fuerzas populares) no asuma orgánica y presencial el poder y lo ejerza como es costumbre en los partidos políticos tradicionales. En el caso tomado como referencia, es un segmento de la organización, los dirigentes con mayor capacidad administrativa, gestiva y de procuración de bienestar para la población los que asuman las funciones de gobierno, respaldado por la estructura política que lo lleva al poder, no obstante, el apoyo ideológico/ político no está dado sin condiciones, sino que mantendrá independencia de criterios, conmina a la deliberación en caso de tomar o delibrar medidas no acorde a la ideología y demandas ciudadanas.

La estructura política/orgánica mantiene independencia y colaboración con el gobierno, enlaza acciones con los movimientos populares y actividades demandantes de solución en la sociedad. No depende de recursos del Estado ni asume rol de correa de transmisión de las políticas públicas, debido a que de hacerlo entra en el engranaje del gobierno y supedita su independencia y actuación a las necesidades de los poderes vigentes.

No es un divorcio entre gobierno y estructura política ganadora de la elección, sino una nueva forma de colaboración con espacios definidos e independencia de acción, con bisagras de contribución, diálogo abierto, crítico, propositivo y en algunas ocasiones con gestión benéfica para los objetivos de 
cada segmento (gobierno y/o partido) porque son necesarios para la reproducción del órgano gestivo organizacional.

No defendemos la traslación mecánica y absurda de la estructura partidaria hacia la esfera gubernamental; en las experiencias anteriores en América Latina, las fuerzas insurgentes que arriban al poder, suben al estrado con toda la estructura partidaria, distribuyen los cargos y responsabilidades de acuerdo a las negociaciones internas y lealtades, burocratizan al partido o agrupación, las desvinculan de las bases, trazan una frontera entre quienes están en el poder y dónde debe permanecer el pueblo, condicionan la participación popular en función de las necesidades de los grupos de interés insertados en el gobierno o a una política nacional que el comando del Estado decida para defender una causa o decisión no socializada, menos discutida ni tamizada por los distintos contingentes del partido.

Las actuaciones de "Bajar Línea", "Comandante Ordene", "Centralismo Democrático" o "Dirección Nacional Ordene" no encaja en los preceptos revolucionarios del Siglo XXI, el pueblo tiene y exige involucrarse, participar, criticar, disentir, proponer y rechazar decisiones que contravengan sus intereses 0 que estén ambiguas en la concepción política del momento que enfrenta. No es aceptable la verticalidad de la obediencia, porque todo acto de sometimiento a partir de un orden impuesto genera una reacción de desconfianza y desarraigo de los colectivos, marca distanciamiento entre la dirigencia y los agremiados, desmotiva la voluntad participativa y van restandoconsistencia a la estructura orgánica revolucionaria.

Sociológicamente es importante tener presente el papel capital que desempeña la interacción social en situaciones de ejercicio político y escenarios de riesgos, porque brinda la posibilidad de interactuar, intercambiar información para identificar los cotos de peligro, de esta manera crean o forjan mecanismos y entendimientos comunes para no aproximarse a las zonas inseguras. La aceptación por parte del segmento social o comunidad de admitir los identificadores de sospecha o peligro acentúa la confianza, carga de contenido los 
depósitos de cordialidad y colaboración y representa una fortaleza del tejido social y en la organización política.

En cambio, en espectros con desconfianza incremental los comportamientos ciudadanos son depositarios de miedos, sumisión y docilidad, todo ello debido a que perciben del entorno y de las estructuras de poder fuertes signos de amenazas a su integridad física y moral, perciben que el medio social no es el mejor resguardo de sus recursos y la vida, ven reducido el ejercicio de la libertad de pensamiento y limitados los desplazamientos dentro la realidad social que lo circunda y a la vez carece de información y pruebas para validar rumores, comentarios, noticias, contratos o intercambio con otras personas o agencias.

Considerando a la desconfianza como el rotor principal que ejerce la mayor fuerza para desmembrar una comunidad, dado que divide y separa a los miembros de toda asociación, es inexcusable practicar el hostigamiento, razón por la cual no es posible construir o tejer un vínculo de confianza a través de recursos de la suspicaciaque dañan la urdimbre social.

Es un asunto cultural en la izquierda latinoamericana, el caudillismo que permeó muchos tramos de la historia desde las primeras insurrecciones en la colonia hasta el Siglo XXI que ahondan en un déficit de democracia interna. Las conducciones políticas padecen de liderazgo compulsivo, adulaciones y lisonjas de parte de los círculos cercanos, predilecciones ante las lealtades, concentración del poder unipersonal y creencias de que puede pensar y conducir una nación sin consultar, debatir o proponer consulta popular. El gobernar obedeciendo no es pieza en el engranaje de su pensamiento, de ahí que cada tropiezo que tienen no es posible recomponerlo en el corto plazo por la desconexión existente entre líder compulsivo y pueblo.

Sería el escenario de un partido que asume gobierno sin abandonar sus funciones organizativas y de exigencias y demandas sociales, una estructura organizativa que cumple la función de sistema venoso o arterial que mantiene la oxigenación entre gobierno y pueblo; el gobierno administra eficientemente y la organización partidaria nutre a los distintos colectivos, sube demandas, acompaña diligencias, gestiones, debate internamente asuntos de carácter político, propone 
nuevas instancias de coordinación y empodera a las comunidades para que ellas desde su lugar, con sus tradiciones, formas de lucha, acervo de conocimiento, memoria colectiva y herramientas políticas realice sus aspiraciones, asuma retos, debata el futuro de su lugar, comunidad, región y nación.

Es necesario abandonar el tradicional lugar asignado de receptor conformista que recibe ideas y obligaciones, a su vez deseche el tradicional lugar de depósito de servicios, responsabilidades y misiones sin mediar una justificación, alegato o prueba fehaciente de la necesidad de llevar a cabo una acción.

Es hora de que la organización tamice y pondere las decisiones gubernamentales, deslinde responsabilidades, el gobierno atiende asuntos nacionales y la estructura partidaria temas y problemas que atañen a lo popular, a la producción, la organización, empoderamiento, capacitación ideológica, ampliación de redes de colectivos, construcción de espacios estratégicos, educación, prevención de violencia y ante todo, mantener la interlocución invariada con el pueblo. De esta manera es posible avanzar en la emancipación, controlar los espacios estratégicos, visualizar riesgos, mantener vigilancia a los desvíos de la dirigencia en el gobierno, exigir cumplimiento de lo prometido en campaña y desburocratizar los procesos revolucionarios.

\section{La infranqueable Franja burocrática}

Los gobiernos de izquierda o "progresistas" casi siempre arriban al poder carentes de experiencia administrativa, gestión ciudadana y en elaboración de proyectos para estructurar planes, acopiar recursos económicos, generar rentabilidad y ampliar las redes de distribución. La administración de la economía es un cuarto negro, las especulaciones y la realidad están divorciadas, las lecturas que hacen de las cuentas nacionales son fantasiosas, centran la atención en lo que perciben o ingresa y no lo calculan o balancean con los egresos, de ahí la causa de los déficit enormes y los flujos de producción y distribución terminan minando las bases de simpatía que la población tuvo al iniciar el proceso de reconstrucción político-social. 
Ante el déficit de cuadros políticos de izquierda preparados para atender la gestión gubernamental, en especial en el área económica, echan mano a cuadros medios de la derecha y en otros casos integran académicos e intelectuales para que armen el cuadrante del nuevo proyecto fragmentado en ideas y copias de lo que han realizado otros países, al final es una colcha de retazos que pretenden darle sello original aunque sus fundamentos son débiles, dado que no hay un diagnóstico veraz y contundente de los recursos del país, los cuales están potencialmente maduros para explotar y en dónde obtener los recursos, no tienen clara la idea en donde capacitar a los cuadros estratégicos de las nuevas empresas, el perfil social sin reñirse con el productivo y la ineludible rentabilidad, la incorporación de nuevas tecnologías, el fortalecimiento del mercado interno, la política salarial sin que sea una sobrecarga para el Estado, la formación de polos de desarrollo, la incorporación de las universidades e institutos tecnológicos a los proyectos nacionales y regionales, otros más focalizados en especialidades que reditúen beneficio a la nación, la priorización de estimular los estudios superiores en ingeniería, física, tecnologías, aprovechamientos de aguas, tierras, selvas y fauna con un equilibrio que preserve a la naturaleza. En fin, son la parte importante de todo proyecto de relanzamiento de una nación que pretende emanciparse y en la práctica son asignaturas de poco interés en los gobernantes de izquierda.

Los académicos cuentan con la inteligencia para interpretar la sociedad, la realidad política y el mundo simbólico de una nación, en la totalidad de los casos hasta ahora observados en Nicaragua 1979, El Salvador en las administraciones de Mauricio Funes (2009-2014) y Salvador Sánchez Cerén (2014-2019), Venezuela desde 1999 a la fecha, Bolivia desde 2006 al 2018, Ecuador del 2007 al 2017 y Argentina de 2003 a 2015, desempeñaron lugares y cargos estratégicos, sin embargo el manejo de sus funciones no fue idóneo con la realidad y el mundo circundante. La cátedra no funciona en gestión gubernamental, mucho menos el discurso político. La gestión política dentro de la administración demanda conocimiento técnico, manejo de variables nacionales y globales, comportamiento de los precios de los productos y materias primas que intervienen en la economía 
nacional, la tendencia de los precios y bonos de deuda y los plazos cotejados con las tasas de interés.

Al final de cuenta esos cuadros académicos fueron extraídos de las universidades dejando una oquedad en la academia y los incorporaron al gobierno creando una ineficiencia, que en el curso de los años fueron convertidos en una densa red de burócratas entre el pueblo y el poder ejecutivo, impidiendo un vínculo de reciprocidad entre el poder y los gobernados. Forjaron nidos y roscas de influencia, experimentaban relatos para elevar el ego y complejizar la comprensión de los problemas, en especial las economías que no tuvieron un manejo apropiado aun cuando en los años que gobernaron con relato progresista tuvieron ingresos enormes por el precio de las materias primas exportadas con valores nunca antes visto. Petróleo, cobre, estaño, gas, oro, plata, litio entre otros recursos que la expansión de China y la India demandó por los procesos de industrialización, agregamos el crecimiento de la fabricación de armas, automóviles, artefactos con nanotecnología, transformación de la actividad naviera, aeronáutica, en fin, un ciclo que nutrió a varias economías latinoamericanas en especial las gobernadas por el llamado "progresismo" pero la burocracia "intelectual" no pudo ni supo entender que los ciclos económicos no son de largo aliento y en cualquier momento la burbuja explotaría.

No obstante el ingreso de tanto capital, algunos países prefirieron importar mercancías antes que incentivar la producción y talento nacional. Se ampliaron derechos en la letra que fueron compensado son subsidios y planes de apoyo económico para familias carenciadas sin estimular la educación y el trabajo de ellos. Los cordones humanos de apoyo político estaban subsidiados, cortaban las iniciativas políticas de reclamo de los pobres y organizaciones barriales, fue la apertura del fomento a la lealtad a cambio de dinero, el adocenamiento total que adormeció la rebeldía y fue sometida a los dictados del gobernante, creyendo que el mandato gubernamental sería eterno, que el acatamiento subsidiado no tenía caducidad y el pueblo siempre votaría por ellos.

Colocar redes de contención con burócratas de mandos medios que se asumen "intelectuales orgánicos" que pretenden remplazar la memoria y 
capacidad de reflexión colectiva de los movimientos sociales y populares con elucubraciones y decisiones absurdas con un claro perfil burocratizado y alejado de la realidad fue un error mayúsculo del ejecutivo o la cúpula del poder, prefirieron construir con narrativas y mitos presidenciales la actividad central del gobierno, incluso fue tan reiterativa que ellos quedaron atrapados y envueltos en la identidad diseñada y narrada por ellos como vestido para el cuerpo gubernamental.

Las cifras no revelaban una necesidad de actuar, fueron veladas con imágenes victoriosas, los reclamos los enmudecieron con dádivas disfrazadas de subsidios, abrieron universidades sin soporte ni perfil, iniciaban obras sin calidad ni supervisión, delegan funciones sin vigilancia, el partido o movimiento social popular se transformó en poder aunque no lo tuvo realmente, el pueblo recibía canonjías y la corrupción afloró. La derecha bajo el manto de Odebrecht, conglomerado empresarial brasileño sospechosamente ligó contratos y obras en los países con gobierno "progresista" y con el filoso sigilo de la corrupción doblegó voluntades, asoció a dirigentes políticos, incorporó a la madeja del soborno a ministros, presidentes, bancos, en fin, dio la estocada a la clase política y la dejó exhibida y sin la cobija de la credibilidad.

La inmovilización a que fueron sometido las organizaciones populares, fue fatal, aunque otras no doblegaron sus fuerzas y demandas y prefirieron optar por una postura independiente, alejadas de la influencias burocráticas como fue el caso de Brasil con el Movimiento Sin Tierra y muchas organizaciones barriales y comunales en Venezuela, quienes observaron con lente prismática los riesgos de la abdicación, porque el muro de contención burocrático pretendían anular las críticas y por ende minar la estructura generadora de sujetos radicales con proyecto popular y construido desde abajo con los de abajo.

\section{Burocratización stalinista}

Toda burocratización excesiva con perfil stalinista conlleva a blindar espacios, construir secretismo, desviar recursos, instalar la práctica corrupta para 
eliminar la insubordinación y rebeldía pero los acerca a la olla putrefacta del capitalismo de Estado o al fracaso de un ideal promovido discursivamente.

El gobierno venezolano a partir de Hugo Chávez F., tuvo, en un inicio, un perfil amplio, incluyente y con vocación plural, sin embargo en la medida que fueron transcurriendo los años y la oposición fue agrupándose de manera orgánica, los militares fueron ocupando cargos ministeriales, gobernaciones, alcaldía de manera preponderante.

El punto de partida fue el año 2000, hubo una asignación creciente de militares en puestos administrativos de dirección para distribuir alimentos, asistir desastres naturales y patrullaje, para el año 2013 existían 1.614 militares ocupando cargos en el gobierno. Actualmente en 2017, de los 32 ministerios, 11 están en manos de funcionarios castrenses traducido a un tercio (33\%) de las carteras claves de mayor relevancia como Relaciones Interiores, Justicia y Paz, con el general Gustavo González López; Economía, Finanzas y Banca Pública.

La estructura orgánica/administrativa es netamente castrense, cuya formación se caracteriza por disciplina de obediencia, mando vertical, imposición de justicia militar, visión unilateral, mando único y la negación de la figura del adversario a cambio de la de enemigo.

La rigidez del mando castrense anula la posibilidad de abrir canales de participación popular, impone su voluntad a los gobernados de manera autoritaria y sin mediación de valoraciones reflexivas por parte de los grupos y movimientos que son parte del engranaje del proceso de cambio en la República Bolivariana. Indudablemente, el dique construido entre el poder ejecutivo y el pueblo está nutrido de una casta militar obstaculizadora de toda negociación y poco a poco relega a las fuerzas populares a una posición de obediencia y abdicación, receptora de mandato y tareas asignada, aceptación de los designio de la cúpula dirigente y desconectada de toda esfera decisional. Eso sí, al momento de crisis, el pueblo relegado debe asumir las responsabilidades asignadas, obedecer las leyes emanadas y decretos de emergencias, aceptar las decisiones de la dirigencia y poner sus recursos y vida al servicio de la patria. 
No es nada distinto a lo que sucedió en la Unión Soviética en los años gobernados por Stalin con furia y tiranía entre 1926 hasta su muerte en 1953. Y la semejanza es corroborada en la manera en que han interiorizado los métodos burocráticos para comunicar a la población, dirigir los procesos productivos, de comercialización, las elecciones, las movilizaciones en las calles e incluso en el relato impuesto donde todo debe calzar en sincronía con el discurso oficial, con la retórica divulgada 0 inculcada de manera ortodoxa. Todo intento de cambiar o alterar el curso de la comunicación gubernamental es objeto de sanción o persecución por deslealtad, traición a la patria, escuálido o contra revolucionario terrorista. He ahí parte de las desafiliaciones e ingredientes de la crisis en la conducción del proceso, cuya "dirección" férrea por parte de la nomenclatura y desde las filas burocráticas e intelectuales pro-stalinistas que los defienden, negando de esta manera la posibilidad de estructuración al sujeto político popular, lo cual es un contrasentido y desviación de todo proceso político emancipatorio.

Los errores cometido son muchos, no obstante lo importante a resaltar y develar es el perfil social stalinista del gobierno y la infructuosa tarea por liberar un pueblo con métodos políticos absurdos, de espalda a los principios democráticos, ortodoxo y vertical que siempre terminan abandonando a su pueblo y lo coloca como bandeja receptora del Estado surtidor, fracasando en su modelo económico alternativo a construir. Los ingresos que tuvo Venezuela en los años de altos precios del petróleo es enorme y hubiese dado soporte a una nueva fisonomía de la economía nacional, claro si la revolución chavista no se hubiese quedado a menos de la mitad, dejando la economía predominantemente bajo el control del capital.

En lugar de ello, la burocracia estatal dirigente se apoyaron en los altos precios del petróleo y sus enormes reservas de hidrocarburos para reducir la pobreza, pero no para transformar la economía a través de la inversión productiva, la propiedad estatal y la planificación. Entre 1999 y 2012 el Estado tuvo ingresos de \$ 383.000 millones del petróleo, debido no sólo a la mejora de los precios, sino también al aumento de las regalías pagadas por las transnacionales. Sin embargo, estos ingresos no se utilizaron para transformar los sectores productivos de la 
economía. Sí, algo se utilizó para mejorar el nivel de vida de las masas más empobrecidas. Pero no había un plan de inversión y crecimiento (Roberts, 2017).

La otra cara de la crisis que elevó los ánimos y provocó efervescencia fue la Constituyente, una decisión apresurada, con notorio desespero por atajar un conflicto desde la postura militar y confrontativa no era necesaria en asumir en esos momentos. Además, el diseño de la estrategia Constituyente tuvo un "carácter corporativista" de la elección, pues los nuevos asambleístas fueron electos sobre una base territorial (364 asambleístas), con un representante por municipio, lo que implicó una sobrerrepresentación de zonas poco pobladas donde el oficialismo es claramente fuerte, y sobre la base de listas de grupos sociales escogidos en la convocatoria (181): trabajadores, pensionados, campesinos, estudiantes, consejos comunales, empresarios, personas con discapacidad e indígenas, muchos de esos segmentos no son vitales para construir las bases de un modelo alternativo aunque no demeritamos su participación. Por ejemplo los pensionados tuvieron una representación mayor que intelectuales, profesionistas, jóvenes y obrero (Márquez, 2017).

A lo anterior, el error Constituyente revela una mayor desazón al integrar la directiva y quienes la conforman, en primer lugar cuatro han sido vicepresidentes de la República, con Chávez o Maduro: Diosdado Cabello, capitán retirado del "número dos" del Psuv; el sociólogo Elías Jaua, el abogado Isaías Rodríguez y el docente Aristóbulo Istúriz. Sumemos a la esposa del presidente, Cilia Flores, Adán Chávez, hermano del fallecido Hugo, losEx guerrilleros en los años sesenta, como Julio Escalona o Fernando Soto, compartirán con militares que acompañaron a Chávez en su rebelión de 1992, y con jefes sectoriales o regionales del Psuv, ex funcionarios, ex parlamentarios e incluso varios que fueron "constituyentistas" en 1999, cuando Chávez impulsó una carta magna (Márquez, 2017).

Burócratas de larga militancia, nulidad en la renovación de mandos, militares insertos y una dirigencia sin aliento, acorazada, sin visión de proceso de transformación, débil en acervo crítico para remontar una situación de crisis, con reparto de cuotas para cuidar sus parcelas de poder, mientras que el pueblo 
resiste y confronta a la oposición y las penurias de una economía que no tiene combustible para seguir funcionando.

Los perfiles stalinista no abonan el terreno de los cambios profundos en las sociedades que están gestando transformaciones políticas fuera de la órbita neoliberal, antes por el contrario, traen lluvia de desencanto, ruptura internas que impiden la continuidad, rebeliones de grupos facciosos, desencanto en la población y dificultades en el futuro para re-editar un proceso de nueva cuenta que revierta los errores.

Ecuador tuvo una conducción liderada por Rafael Correa con un corte unipersonal, el movimiento La Revolución Ciudadana no fraguó como tal, más bien fusionó o amalgamó varias agrupaciones civiles, dieron forma a un frente con un cometido electoral/gobernar sin incidir en la los rincones del pueblo, no fue más allá de del trabajo político electoral en torno a los agentes postulados, los referentes políticos sin penetrar ni permear sectores ávidos por comprometerse en la lucha, de empoderar grupos de trabajadores en el campo, armar proyectos locales, promocionar nuevos liderazgos, dar curso a escuela de cuadros políticos que fuesen renovando la plantilla vigente, integrar nuevos militantes con férrea voluntad de involucramiento y compromiso y no bajo la bandera de recibir canonjía, prebendas o cargos dentro del gobierno. El Vicepresidente de Alianza País hace un llamado al aire, sin interlocutor directo, afirmando que el pueblo ecuatoriano votó por la Revolución Ciudadana y por eso debe continuar, aunque se deben corregir errores, frase cargada de desesperación y sin canales adecuados para llegar a un núcleo de población. La página de Alianza País http://www.alianzapais.com.ec/ sintetiza y evidencia las debilidades de una organización política que pretende inscribirse en la izquierda trasformadora.

La militancia en la mayoría de los procesos políticos "progresistas" tuvo sediciones y deserciones de fuerzas importantes exigentes de mayor celeridad y profundidad en los cambios de ahí la postura del Partido de los Trabajadores de Brasil: Vencimos una elección. No hicimos la revolución socialista, marcando la distancia con el gobierno de Lula en el mes de noviembre del año 2000. El Partido Comunista y otras organizaciones en Venezuela tomaron distancia con la 
imposición desde el gobierno de la estructura orgánica PSUV (Partido Socialista Unido de Venezuela) incluso organizaciones comunales y parroquiales de muchos años de trabajo focal no fueron incorporadas al PSUV sino que los invitaron a abandonar sus plataforma y se fusionaran en el partido del gobierno. De igual manera aconteció en Argentina, un gobierno de corte nacional con serias deficiencias para trazar las líneas programáticas, navegó entre un peronismo descolorido y un liderazgo familiar con serias deficiencias organizativas, un relato pre construido y desfasado de la realidad, con mandato vertical y condicionando a las organizaciones barriales y populares a plegarse a cambio de algunas concesiones, restándole la mística a la militancia, adocenando a los dirigentes y desvertebrando luchas que ya habían recorrido un camino considerable.

\section{Resultados de los procesos "progresistas"}

Si me preguntan, ¿qué resistencia hay en América Latina? Respondo... Una acción colectiva explosiva con respaldo orgánico y espacios estratégicos empoderados, con capacidad de instrumentar una guerra de movimiento. No la hay.

Una expresión emotiva de hartazgo y de irrupción en las calles, es posible pero expuestos a una represión mayúscula puesto que las policías ahora utilizan tácticas militares y de eliminación del enemigo...sería costoso porque inundaría el ambiente con miedo y diáspora fragmentadora de lo poco que existe.

Una latencia de algo nuevo puede darse, la miro desde los siguientes puntos a analizar 1/ Evaluar las fortaleza/debilidades del enemigo; 2/ Caudal de herramientas políticas y formas en como elaboran las demandas los movimientos populares y la manera en que la insertan en la realidad social, 3/ posibles alianzas estratégicas y coyunturales entre sectores sociales y populares para construir una acción colectiva 4/ pautar los tiempo y los espacios de la cotidianidad política, observando si la crisis llegó a las casas, las esquinas, a las aulas, en los espacios públicos y en el debate público.

Todo esto hasta ahora no está presente, el debate lo impone la opinión prefabricada de los medios y la derecha; la mesa diaria es de lamento, crítica y 
supervivencia aislada, la brecha entre lo popular y los sectores medios es enorme y por último, los reclamos y petitorios se rotan, son tomadas de otros lados, son refritos y nada es nuevo; está agotada la creatividad para posesionar o sembrar una reivindicación o exigencia, enlazarla con acciones de denuncia y convocar a otros en situación similar es un camino sinuoso. Entonces, vivimos un escenario de demandas sin nutrientes ni inyectores de acción, reclamos ruidosos sobre los actos de gobierno y una política contestataria ante la pauta de opinión pública que imponen los medios. Esa es la nube que pesa sobre el año 2018.

El otro segmento de dudas es ¿hasta dónde el ejercicio democrático que ejercieron los gobiernos "progresistas" brindó un avance en la concepción de la democracia?

Desde el punto de vista de las instituciones globales encargadas de evaluar la llamada Calidad Democrática, los países con gobiernos populares fueron calificados entre 2.4/ 3.0, en escala de 10, según los parámetros que fueron medidos en temas de: participación política, derechos civiles y políticos, libertad de prensa, división de poderes, corrupción, represión, inseguridad económica, leyes de transparencia e información y gestión de datos no fueron confiables.

Si la mirada la situamos en la acera de los movimientos populares, los señalamientos van desde la exclusión de los diálogos sobre temas claves, hasta el desconocimiento de sus autonomías y frentes de lucha. Indudablemente, el déficit democrático va de la mano del liderazgo compulsivo, la intolerancia ante los reclamos de otros sectores populares, el centralismo democrático en versión de cúpula o nomenclatura que toma decisiones trascedentes, la tendencia de uniformar voces alrededor del gobernante, impedir la toma de iniciativas fuera del centro de poder, la imposición del relato identitario del gobierno como carta de presentación de todas las fuerzas políticas y la exclusión estigmatizada de las voces y actividades disidentes con epítetos de apátrida, contrarrevolucionario, enemigo del pueblo, terrorista, anarquista, sedicioso y hasta traidor.

La izquierda está necesitada y urgida de una reflexión colectiva, autocrítica y de cara a la sociedad. Debe abandonar la secritud, dejar de esconder sus errores y desviaciones, abrir ante el pueblo la vocación de cambiar, de acompañar 
al pueblo y aceptar desde las voces del pueblo vengan señalamientos y reproches, dado que la democracia es así, plural, franca, accesible, libre y comunicativa. Nada es posible guardar si tras de ese secreto hay evidencias de yerro, injusticia, omisiones y culpas. La democracia vive y tendrá éxito si somos capaces de aceptar las equivocaciones y decisiones con desatino, ser franco ante lo mal hecho es la opción futura y será la horizontalización de las deliberaciones, la socialización de las grandes decisiones y la estructuración de una vanguardia colectiva que acompañe al pueblo y a su vez esté alimentada de la masa que preconiza, anhela y lucha por un cambio emancipatorio.

\section{El qué hacer del Sujeto Insumiso: Caja de herramientas: definición y características}

En la alforja del Sujeto Insumiso están las herramientas de luchas, las ideas almacenadas para ser activadas en coyunturas y circunstancias apropiadas, la disposición y habilidades para construir articulaciones con otros movimientos populares, los espacios estratégicos en que recargan nuevas formas de lucha en situaciones de latencia, reconstrucciones de debates ideológicos y escuelas de cuadros para reproducir liderazgos horizontales y novedades en el ejercicio de prácticas políticas de acuerdo a las mutaciones del enemigo.

Toda caja de herramientas es dinámica, permanentemente están incrementándose los acervos mediante la activación de los reproductores ideológicos, que son inteligencias populares observadoras de manera minuciosa del comportamiento del enemigo, las expresiones discursivas y los desplazamientos estratégicos desarrollados a cada momento, dado que muchas de las veces, la palabra y el discurso son señuelos para avanzar en el campo militar o del despojo, justo en ese desencuentro entre lo real y el discurso, en los intersticios sociales penetra la observación, la conjeturas, el armado de premisas que articulan las piezas de cada movimiento del enemigo donde más tarde son discutidas colectivamente para construir de manera conjunta la mejor estrategia de confrontación, los desplazamientos en las protestas, el diseño ideológico de la 
demanda y la apertura necesaria de la reclamación para que encaje, embone con otras preocupaciones y necesidades del conjunto de lo popular.

Muchas veces la guirnalda de las demandas es amplia, diversa, multicolor y con dimensiones irregulares, dicho en otras palabras, son de corto plazo y otras de mayor aliento, de ahí que las demandas de carácter articulada debe ofrecer vínculos, enlaces y traslapes con otros cuestionamientos devenidos del campo popular con el objetivo de preparar un entramado escalonado que posibilite ir dando cuerpo a un programa amplio, asociado, colectivo, con vector horizontal que dote de la misma importancia cada vindicación, que la fuerza gremial dirija con la misma vehemencia sus capacidades reclamantes de una demanda focal como la de una exigencia de mayor envergadura o de alcance regional o nacional. Cada una tiene un valor que consustancialmente está ligado a la estrategia global del movimiento popular.

La derrota en uno de los frente de lucha, aun siendo en un espacio acotado, el enemigo la enarbolará como la obtención de una gran victoria que indudablemente tendrá la resonancia divulgativa que ideológicamente reproducen los medios de comunicación. La perspicacia de la divulgación ideológica es un factor disolvente en los cuerpos populares, de ahí que cada lucha, por pequeña que sea, es importante porque cimenta la plataforma de lucha, dota de amplitud el frente ofensivo e incorpora y multiplica a los distintos movimientos, gremios, auto convocados, los nuevos precarizados (Maza, 2004).

Los rebeldes e insurrectos que aplazaron la militancia y en las circunstancia del Siglo XXI otean la posibilidad de reinsertarse en la lucha.

La caja de herramienta es el mayor capital del sujeto insumiso, de ahí que es menester renovar permanentemente el arsenal que es distinto a remplazarlo. Reorganizar es escoger la mejor táctica del momento, diferenciar lo coyuntural a lo estratégico, eslabonar las demandas, seleccionar los espacios de movilización, el horario de las tomas de calles y avenidas, situar el reclamo de acuerdo a la zona habitacional o transitada, seleccionar el contenido de lo reivindicado, dejar claro las pretensiones y no dejar espacio a la duda que conlleve a la argucia, resituar 
exigencias aplazadas y ante todo, disponer de un lenguaje diáfano, popular y conciso que no dé cabida a varias interpretaciones.

El desuso de la caja de herramientas y/o aferramiento a persistir en mantener una conducción vertical, liderada por una persona con acento compulsivo de mandato unipersonal, conlleva irremediablemente a la desintegración del movimiento popular. El discurso imperioso y absorbente no es una forma de lucha ni un elemento atrayente para los sectores que están buscando una participación en la lucha. Imponer un discurso es anular la capacidad dialógica de los sujetos, impedir la construcción de articulaciones con otros movimientos o fuerzas políticas, es negar que la realidad social es distinta a las percepciones que tengamos de ella, amuralla la asociación perceptiva de los distintos sujetos, amordaza las discusiones internas, ahuyenta el disenso, debilita las estructuras orgánicas del movimiento, abre fisuras y da pie a intersticios sociales fomentados por la unilateralidad y la pretensión hegemónica de liderazgos compulsivos.

Dar las espaldas a la renovación de la caja de herramientas e impedir que sea una tarea colectiva, abre las puertas a los desapegos, a la animosidad y disconformidad entre los agremiados, los que perciben que sus capacidades son incompatibles, menospreciadas y sin anclaje en la estrategia global, revelando un agotamiento en la forma de conducción, estrechez en los canales de comunicación interna, parálisis en las movilizaciones, retórica reiterativa, creación de círculos concéntricos en las esferas de mando, reconocimiento a las lealtades por encima del trabajo la aportación en la lucha, asignación de responsabilidades sin consentimiento y estimación de aptitudes y valor superlativo a la autoridad en detrimento de la voz del colectivo. Todas estas anomalías con los síntomas de lo que se conoce como mesetización de un movimiento popular que abandona las toldas de la insumisión por el exceso de burocratismo e inmovilismo en la lucha popular. 


\section{Escenario habilitante de nuevas herramientas políticas}

Las nuevas herramientas de lucha están elaborada de acuerdo a las características y mutaciones del enemigo. A partir de la crisis del modelo neoliberal, el avance de la derecha en los escaques del gobierno y en los espacios de reflexión, en la recreación de saberes, en los cuerpos judiciales, medios de comunicación y en la enseñanza. Es una nube ilimitada y densa que cubre la enorme capilaridad del cuerpo social con la intensión de asfixiarla y negarle todos las zonas de contra-ofensiva, de rehabilitación de espacios de lucha, debates, discrepancias y rivalidad.

Es una derecha que denota un conservadurismo distinto a la esencia y comportamiento que esgrimió en el Siglo XX y los primeros diez años del Siglo XXI, esta vez re-surge con rostro distinto, discurso escurridizo que transita entre populismo nacionalista y represión militarista, constructor de nuevos enemigos y confrontativo frente a las ideas liberales y socialistas.

Si el enemigo manifiesta las siguientes características:

Deja al descubierto una ruptura total con todos los movimientos y partidos de extrema derecha, defensores del liberalismo y socialistas.

No tiene lugar ideológico definido, navega en aguas turbulentas y sin color, denotando una postura de defensor de la nación a través de construcciones sociales discursivas de enemigos externos (migrantes, homosexuales, criminales, entre otros) enfatizando la protección del país a través del odio tribal y la opción por el uso de la violencia.

El travestismo ideológico y la manera en que seducen a los adeptos y votantes es a través de una promoción No Militante, sino de pertenencia a una "comunidad" con ideales nacionalista, defensores de la libertad plena, abocada a congregar jóvenes, intelectuales y empresarios mediante "membrecía" de nuevos ciudadanos del Siglo XXI, alejados de toda ortodoxia ideológica, abierto a hombres que tengan vocación intelectual para defender las ideas, credo o acciones instrumentadas. La ortodoxia no está dibujada en la parte discursiva, deja abierta la posibilidad de que fugas producidas en las filas de la izquierda o la derecha 
tradicional tengan cabida en su "comunidad" y conjuguen las ideas pero dentro de la vocación del nacionalismo xenófobo y criminal.

Algo que es importante destacar en la trayectoria comportamental del movimiento de la derecha Siglo XXI, es su movilidad en dos aguas, la política y la cultural, aunque las dos están interconectadas, en los debates, piezas discursivas, promoción del voto y defensa de sus ideales, fracturan todo arreglo ideológico, volatilizan los modelos de lucha, de sociedad futura, de razonamientos políticos y de formas de lucha, es un mapa sin frontera y masa amorfa que desubica al enemigo y se cubre de toda crítica que venga del adversario o enemigo. Libertad, bienestar, oportunidades a jóvenes intrépidos capaces de quebrar todo orden y crear condiciones para el libre arbitrio sin medir consecuencias, decididos a transitar vertiginosamente por las carreteras del internet e impregnar a la sociedad de imágenes, frases, ridiculizaciones que quiebran mitos, tabúes, tradiciones y costumbres alojadas en las subjetividades colectivas. Sus seguidores son provocadores compulsivos, sembradores de minas en el subsuelo de la sociedad que intentan romper y enterrar todo vestigio de organización social y del buen ejercicio de la política.

Si bien es cierto que el orden social había perdido las coordenadas de la estabilidad orgánica por los embates del mercado y su incidencia en todas las esferas de la vida, el complemento que generó un quiebre fue el fundamentalismo de la libertad de expresión, el cual confronta toda idea de multiculturalismo anidada en la era global. Fue la estocada para derribar el mito de la sociedad y democracia global.

Hay una apuesta a un neo tribalismo que está incubado en los fracasos y desorden de la globalización, que simboliza el reagrupamiento de los miembros de una comunidad específica con el fin de luchar contra la adversidad que los rodea, sólo que esta vez los infortunios y calamidades están prefabricadas desde los centros de poder de la Nueva derecha que alimentan y diseminan piezas de su credo por los medios electrónicos, centros de saberes y lugares de trabajo. 


\section{Redes y acción directa (expropiando al enemigo)}

Las redes sociales y de personas han alentado la asociación por identidad de oficio, comparten piezas discursivas de ideología, divulgan acontecimientos que se dan en otros lugares, ofertan servicios, mercancías, asesoría, cursos e innovaciones tecnológicas, crean tutoriales, trasvasan conocimientos y saberes, conminan a la solidaridad y apoyo de causas nobles y hasta boicot a comercios y gobiernos que agreden la economía o movimientos populares.

Las redes no son espacios de vicio ni lugar virtual que distorsionan la realidad concreta, los beneficios que descubrimos son innumerables, las bibliotecas virtuales que sobrepasan los cinco millones de libros es un logro encomiable, la solidaridad con respecto al proceso de paz en Colombia, los apoyos para evitar desalojos, extinción de especies reservadas, enlaces informativos que divulgan sucesos y textos ilustrativos sobre lo que ocurre en el instante en el mundo de la política, es un trabajo loable, rico en contenido y ante todo, eficaz para ir minando el reinado de la televisión abierta que entró en el túnel de la crisis por la forma en que las redes desplazaron la caja de mentiras que daban soporte a los gobiernos de turno.

Tomamos en consideración lo descrito y no dudamos en afirmar que en las redes sociales se incuba una nueva representación y práctica de la acción directa propia del Siglo XXI. Si la Acción Directa nos refiere a formas de acción contenciosa que no se encuentran mediadas por la institucionalidad dominante, dado que se expresa al margen de los patrones de conducta regulados por normas y cuya transgresión por ende se convierte en objeto de sanción en los cuales los individuos son socializados. Entonces las acciones directas forman parte de ese conjunto de lucha proscriptas por el ordenamiento institucional dominante (Rebón y Pérez, 2012). No remplazan las anteriores expresiones de Acción Directa, antes por el contrario, agrega, suma, alienta a una presencia reveladora de acción política libertaria, dado que no responde a ningún procedimiento de libreto ejecutado por partidos políticos tradicionales, tiene un carácter espontáneo, súbito y con plena autonomía con respecto a los colectivos políticos instaurados en el mapa social. Es posible que algunos perciban lo 
impredecible de sus actuaciones como el mayor factor que niega la existencia de su conciencia, parte de un añejo debate entre lo espontáneo y lo consciente.

No obstante otras vertientes analíticas nos aproximan a descubrir las virtudes de la actuación súbita en las redes sociales, donde realzan el papel fundamental de la espontaneidad, develando un nuevo formato que adquiere la revuelta o insumisión por el carácter auto convocatorio, donde las consignas preelaboradas y las estructuras pre-existentes no se encuentran en la base de la Acción Directa, menos aún son reconocidos los liderazgos personales de larda data, tampoco son las expresiones de una determinada clase social, dado su cuerpo heterogéneo, sin lugar físico pero con actuación efectiva y contundente para boicotear, convocar, censurar, criticar o demandar un petición justa y reivindicativa

Lo espontáneo es una expresión manifiesta cuando el sujeto ha permanecido largo tiempo en la latencia, espacio y tiempo donde se van gestando los elemento embrionarios de lo consciente, si lo entendemos como la acumulación de experiencia social, de saberes, de desengaños, errores y fuerzas que le sirven para actuar en el momento en que el terreno político le es favorable (Salazar, 2014).

En conclusión, estamos frente a un contexto de lucha desde lo virtual para cambiar lo real; lo real conviviendo en plena contradicción con las acciones virtuales, nueva Acción Directa que exhibe inesperadas herramientas de actuación política, un sujeto en insumisión que decide apropiarse de las redes, vuelca su descontento a la suma de voluntades para abrir un abanico de posibilidades orientadas a confiscar gran parte de las redes sociales, dotarlas de sentido, acomodar sus vínculos y acciones en la realidad social e irradiar de manera colectiva en favor de proyectos populares, medidas reivindicativas, detener el ultraje, las expoliaciones y ante todo detener las guerras y los fraudes electorales.

Después de esta búsqueda y usurpación de las redes sociales, no sabemos la reacción de los dueños de este invento que nació para dominar y puede ser mutado a convertirse en un vehículo de Acción Directa propio del Siglo XXI. 
En la misma dirección, las acciones colectivas, tanto reales como virtuales pueden confluir en un debate, también incidir y volcar sus esfuerzos en afinar dónde y cuándo ejercitar sus herramientas de boicot, denuncias, divulgación y trasmitir parte de los resultados obtenidos para afianzar los avances estratégicos de un movimiento, una elección, una lucha focal, movilización por protesta en el ámbito nacional entre otras, con el fin de ir construyendo canales divulgativos, estructuras informativas, impronta, distinta de las distorsiones que puedan propagar los órganos del enemigo o del régimen imperante.

Contar con canales autónomos para vehiculizar noticias, confrontaciones, revueltas, tomas de espacios públicos, aprehensiones de militantes, grescas contra cuerpos militares, bloqueos de vías en distintos puntos de una ciudad, región o país, es importante en la medida que posibilita que los otros gemíos, movimientos o colectivos sociales instrumenten acciones similares, inyectan arrojo, coraje, valor e intrepidez en los otros para que ellos emerjan de sus espacios controlados o estratégicos con nuevas prácticas políticas, irrupciones de carácter inusitado, singular y súbito que conlleven a descontrolar al enemigo. La comunicación efectiva, ajustada a la realidad, centrada en el objetivo de lucha y acoplada con el tiempo de la lucha que está desarrollándose es vital para no caer en equivocaciones, también evita distorsión del objetivo central y concertado y ante todo, que la fuerza no destruya el entramado de la razón, la lucidez y la conducción de la lucha que están sosteniendo. Una comunicación cargada de espejismo y ficción puede ser fatal, porque la forma o apariencia es parte de una percepción elaborada en medio de la ofuscación, sin embargo, si es socializada entre varios cuerpos perceptores de cada gremio insumiso, es factible conjugarlo en el corto tiempo, valorarlo entre factores de distintos lugares, sopesarlo en medio de los desplazamientos del sujeto colectivo y la capacidad de respuesta que el enemigo está ejerciendo en cada zona donde está la confrontación. Es imprescindible que el factor tiempo esté del lado del sujeto insumiso, a través de las redes sociales, que la inmediatez sea elemento constituyente de la lucha popular, lo súbito coadyuve en llevar adelante la estrategia en la medida que la 
actuación repentina tenga el perfil idóneo de una emboscada que precipite un estado de desesperación en el oponente.

De la misma manera la comunicación insumisa trasmite rutas de desplazamiento del enemigo, arsenal bélico utilizado, número ( aproximado) de dispositivos movilizados, zonas donde existen confrontaciones, tiempo de arribo, confluencias de rutas, mapa logístico de los traslados, intercambiar tácticas y recursos para bloquear arribo de vehículos militares, remoción de grupos de resistencia y colocación de nuevas trincheras para resistir o realizar acción súbita.

\section{Articulaciones y no alianzas}

Las experiencias y aprendizajes fraguados en la militancia activa, en los ajustes cotidianos dentro de la organización, las elaboraciones perceptivas de manera colectiva para construir y conocer al enemigo transitan por los predios de los espacios de movilización, confrontaciones y lucha. No hay experiencia en el sujeto insumisos que esté totalmente inmerso en lo virtual porque perecería. Su fortaleza está en saber manejar los dos escenarios, dotarlos de sentido, asignarle un valor en la lucha y conocer los alcances de cada realidad: la virtual y la realidad social.

El exceso de ejercicio virtual conduce a desfasar la lucha y a colocarla en un plano vulnerable, ineficaz, donde las capacidades del sujeto van disminuyendo por carecer de anclajes con las respuestas que la sociedad pauperizada y marginada está buscando.

Su lugar es el campo de lo popular, donde el vínculo con cada sector le ofrece una lectura amplia y viviente de la evolución que mantiene la realidad social; le permite convivir insertado en el mundo de vida y del trabajo de los precarizados le brinda un instrumento que mide, de la misma manera que lo hace un termómetro, la condición de lucha de los insumisos, el potencial de movilización que va tramándose entre los distintos actores, los mapas perceptivos de lo que acontece, el impacto de las carencias en su vida cotidiana, la disposición de lucha, necesarios para confeccionar un plan de trabajo de acción combativa desde los 
compendios de cada familia, grupo y actores que son parte del contexto intrincado donde reside.

Alejarse del entramado complejo del ambiente donde se re-crea el sujeto es confinarlo a una condición de infecundidad desolada, esto es, desconectado de su medio social-político, atrofiado en sus enlaces comunicacionales, disfuncional para los propósitos de la colectividad y desligado de un plan de lucha efectivo que rinda y produzca avances en los luchadores en suentorno.

Las veces que el sujeto popular tuvo la osadía de alejarse del entorno cotidiano donde fue incubado y aprendió a luchar en el fragor del horno del reverbero que calentaba, disipaba y combatía los agobios y contingencias cotidiana, la estructura orgánica decayó, languidecieron sus prácticas política, asumió un rol de agente difusor de medidas y políticas de gobiernos "progresistas" o de "izquierda moderada" que al final minó sus destrezas, mutiló las aspas de movilización, la cadena de vínculos quedó oxidada, el lenguaje de lucha lo confinó al orden legitimador del gobierno en turno, institucionalizó sus desplazamientos y prácticamente de sujeto aglutinador de ideas, demandas y reivindicaciones pasó a asumir el papel de agente interlocutor del gobierno, mediador de prebendas, movilizador y distribuidor de recursos públicos, extensión del aparato gubernamental y proclive a condicionar su lucha por demandas y reclamos de carácter monetarizados, cuya esencia encubierta es la de permitir la asignación de un precio relativamente objetivo y estable a los servicios prestados al gobierno. Con ello los gobiernos en turno cooptaron a muchas organizaciones populares, obtuvieron gobernabilidad y estabilidad política, crearon barreras de contención de reivindicaciones añejas y legendarias, mejorando sustancialmente la gestión y el control de los recursos en áreas de influencia política que le redituaran utilidad electoral.

En casos como el escenario dibujado, los movimientos populares no evolucionaron, la insumisión no brotó, quedó en la intención y el relato pero fue interrumpido y malogrado por hallar en el camino de la institucionalidad y el orden una situación cómoda pero determinante para mutarlos a agentes progubernamentales. 
El sujeto Insumiso no es parte de alianzas con sello de "pacto de sangre", la lógica de lucha encaja en la articulación con otros movimientos y colectivos sociales, donde el carácter de la demanda de los "otros" embona con la que ellos representan y lanzan al escenario reivindicativo, el lugar de la demanda se asigna o coloca en la cadena de actuaciones y movilizaciones de acuerdo a la coyuntura, los dispositivos de lucha, la incorporación de gremios y auto-convocados, la magnitud del espacio y el horario político. Sincronizar el reloj de las luchas tiene en cuenta los movimientos del enemigo y el resultado que arroje al equiparar arsenal y capacidad de respuesta que tiene frente a la represión.

La independencia persiste dentro de la articulación dado que no es fusión orgánica, sino conjunción de intereses, vínculos estratégicos, enlaces de formas de lucha, coyunturas que favorezcan el avance de la estrategia mediante bisagras en desplazamientos, divulgaciones, denuncias, hostilidades puntuales y defensa de espacios estratégicos controlados.

La supeditación y subordinación ante un gobierno "progresista" o de "izquierda Moderada" es la renuncia los propósitos mayores: la autonomía, libertad y esencia emancipadora.

Finalmente, dos planos de confrontación se observan en la coyuntura prolongada del Siglo XXI y el advenimiento de la Nueva Derecha son:

(1) El Sujeto Insumiso debe evitar o des-monetizar las demandas, dado que el mercado orilla a que la demanda tenga un contorno netamente economicista, asequible de atender en los límites de la confrontación, siempre buscando llegar a un punto de inflexión para conceder el reclamo pero lo agota en el terreno del intercambio monetario a fin de desdibujar el mapa de la confrontación política en el imaginario del colectivo y lo instala en la bandeja de transferencia de recursos públicos o benevolencia del empresario.

(2) La táctica prominente de la derecha es desmontar la percepción de rebeldía en los sujetos reclamantes; porque el objetivo ofensivo de los gobiernos de derecha ( también progresistas y moderados) y empresarios, es romper las vestiduras de sus demandas que son cruzadas por lo económico, la intención manifiesta es exponerlos ante la sociedad como actores con un alto contenido 
disolventes de paz, enemistados de la tranquilidad, atraídos por el dinero, encaminados a apropiarse de recursos que no merecen, hostiles al trabajo productivo, contrapuestos a los intereses de otros grupos y colectivos sociales, irreconciliables con la gobernabilidad y dispendiosos en una circunstancia de crisis.

Por esas razones es preponderante que el aspecto monetario quede en un plano complementario, sin esconder ni desplazarlo de su valor intrínseco, pero no debe aparecer como la égida del movimiento reclamante. Lo político tiene un valor mayúsculo y si queda arropado o rebasado por el factor económico, la lucha está desvirtuada, la insumisión no manda señal y el conflicto acaba con la satisfacción del acto reclamado.

Concesión económica no es un objetivo o logro en la acción reclamante del sujeto insumiso, si bien mejora la percepción salarial, su efecto es temporal, casi siempre desde las esferas de gobierno o los empresarios, la erogación es recuperable con tasa impositiva o incremento del precio de los productos 0 mercancías que los trabajadores crean. En cambio los resultados políticos a su favor son costes no cuantificables en moneda corriente pero si una inyección de victoria, de fuerza, incremento y confianza en sus capacidades movilizadoras, es derrota al miedo, la vulneración que deja huella en el cuerpo de enemigo, es el sello de una confrontación donde midieron fuerzas dos contingentes y el explotado impone las condiciones para proseguir creciendo como sujeto insumiso.

Por lo anterior, la confrontación de hoy lleva la firme intención de desvertebrar el mercado en su esencia, esto es, que no cumpla el cometido de imponer la lógica e incremento del consumo. Toda acción reivindicativa debe contar con un arsenal comunicativo suficiente en canales y vehículos informativos para que el mensaje llegue de manera expedita a los sectores involucrados en la confrontación política e ideológica. Si la lucha está en gran parte en debilitar la estructura del mercado, que el consumo no persista como andamiaje vital en la vida cotidiana, que los empresarios y gobiernos neoliberales teman la caída de ventas, valores, acciones, bolsa mercantil y competencia, es hora y decisión de mantener el boicot, la acción directa a través de las redes sociales, las 
movilizaciones y ocupación de los espacios públicos como el arma que traba al mercado y consubstancialmente las ganancias de los expoliadores que niegan, reprimen y criminalizan a los trabajadores, indígenas y a los precarizados cuando ellos demandan y exigen sus derechos.

\section{Referencias Bibliográficas}

Márquez, Humberto. (2017). Venezuela: Constituyente combativa y combatida, en Revista Sin Permiso, Extraído de http://www.sinpermiso.info/textos/venezuela-constituyente-combativa-ycombatida Consulta: 01/12/2017.

Martínez, Néstor. (2016). Entrevista a Frei Betto. Los errores de la izquierda son no organizar ni politizar al pueblo, extraído de: http://www.rebelion.org/noticia.php?id=211109 Consulta: 01/12/2017.

Maza, Octavio. (2004). El trabajo, una nueva lectura desde los procesos de precarización. Revista Polis: Investigación y Análisis Sociopolítico y Psicosocial, vol. 2, núm. 4, segundo semestre, México. (Pp. 91-112).

Rebón, Julian y Pérez, Verónica. (2012). Acción directa y procesos emancipatorios. Conceptos y fenómenos fundamentales de nuestro tiempo. Universidad Nacional Autónoma de México. México.

Roberts, Michael. (2017). La tragedia de Venezuela, en Revista Sin Permiso, extraído de http://www.sinpermiso.info/textos/la-tragedia-devenezuelaConsulta: 01/12/2017.

Salazar, Robinson. (2014). Los usos efectivos de las nuevas herramientas políticas del sujeto insumiso. Extraído de: http://conceptos.sociales.unam.mx/conceptos final/640trabajo.pdfConsulta: $01 / 12 / 2017$.

Serrano, Ana Lucía. (2011). La entrega de Joaquín Pérez Becerra: ¿un punto de inflexión en la Revolución Bolivariana en Venezuela?, extraído de: http://www.herramienta.com.ar/herramienta-web-8/la-entrega-dejoaquin-perez-becerra-un-punto-de-inflexion-en-la-revolucionbolivarConsulta: 01/12/2017.

Territorio Digital. (2016). Uruguay: crisis de tambos por deuda de Venezuela, extraído

de: http://www.territoriodigital.com/notaimpresa.aspx?c=5645354354090298 Consulta: 01/12/2017. 